\title{
Gender Dynamics in Academic Networks - a Narrative Review
}

\section{BY Mathilde Cecchini, Maria Lehmann Nielsen AND EA Høg UTOFT}

\begin{abstract}
Progress towards gender balance among senior faculty in Danish academia remains slow. Although networks are widely recognized as key to career success, studies on the influence of gender on network dynamics and career advancement in academia are scarce. Until now, scholarship has engaged with the topic of gender and networks in organizations through two co-existing, while unrelated, streams of research, namely the social networks literature and the gendering networks literature. In this narrative review, we ask the following question: What characterizes the social networks literature and the gendering networks literature, and how can they inform each other and advance our understanding of gender dynamics in academic networks? We outline the main findings from the two literatures and discuss the potentials of combining different theoretical perspectives for understanding gender and networks in Danish academia. More specifically, we argue that the social networks literature maps the network structures of men and women, while the gendering networks literature takes us on a journey through these structures. This paper constitutes the first step of a research project entitled Gender and Networks in EarlyCareer Academic Advancement.
\end{abstract}

\section{KEYWORDS}

Gender, networks, career, homophily, masculinities, academia

Ea Høg Utoft is Ph.D. candidate at the Danish Centre for Studies in Research and Research Policy (CFA) at Aarhus University (AU).

Maria Lehmann Nielsen, MA in Educational Sociology, works as research assistant at CFA.

Mathilde Cecchini, PhD, is Assistant Professor at the Department of Political Science at AU.

The authors are all involved in the project Gender and Networks in Early-Career Academic Advancement of which this paper is part. 


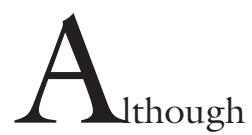

female university students outnumber their male peers in Denmark, women remain a minority among university faculty, and the share of women decreases at every career step (Danish Ministry of Education and Science (DMES) 2017). The processes leading to gender inequalities in the career development of academics are complex and multifaceted (Caprile et al. 2012; Fox et al. 2016). Nevertheless, scholarship often identifies networks as key to understanding divergent retention and advancement rates of male and female researchers (e.g. SmithDoerr and Powell 2005; Whittington 2008; van den Brink and Benschop 2013). However, solutions to women's limited access to influential networks are often presented in a misleadingly simplified manner as if networks are unproblematically available to them and placing the responsibility to network on women themselves (e.g. DMES 2005; 2015).

Gender dynamics in networks in knowledge-intensive organizations such as universities have been the subject of study in scholarly work. Based on a selective, narrative review (Lewis 2014; Cronin et al. 2008; Hammersley 2001) of this literature, this article argues that the relationship between gender, networks and career outcomes has been theorized and examined from two different perspectives. One stream of literature focuses on mapping the network structures of men and women and explaining gender inequalities in career outcomes. We label this the social networks literature. On the other hand, there is also a multidisciplinary stream of research on networks originating from, for instance, sociology, organization and management studies, policy studies and gender studies, which is generally interested in exploring how gender and inequality are produced, reproduced and challenged in the context of organizational network interactions. We label this stream the gendering networks literature. Whereas the social networks literature uncovers network structures and gender inequalities in networks and their implications for career outcomes, the gendering networks literature focuses on how these gender inequalities in networks arise through gender practices in everyday work life.

The aim of this article is twofold. While we do not claim to be exhaustive in our review, we aim to give an overview of what characterizes studies on gender dynamics in networks in terms of theoretical perspective, methods and findings. Second, the article seeks to discuss how different theoretical and methodological approaches could be combined when gender dynamics in Danish academia are examined. The article therefore asks the following questions:

What characterizes the social networks literature and the gendering networks literature, and how can they inform each other and advance our understanding of gender dynamics in academic networks?

We argue that combining insights from social networks literature and gendering networks literature advances our understanding of the complex relationship between gender, networks and career outcomes in academia. We propose that in order to understand why gender differences in the network structures of men and women arise, as mapped in the social networks literature, it is necessary to examine how gender is practiced and constructed in networks and networking, which the gendering networks literature can facilitate. At the same time, limiting our focus to understanding how gender is constructed in interactions between individuals through the lens of the gendering networks literature is not enough if we want to uncover general patterns of inequality and their implications for career outcomes. For general patterns, we need the social networks literature. We 
therefore posit that combining these two perspectives is a fruitful approach if we want to advance our understanding of network dynamics in academia, an aspect of gender inequality at universities that has thus far been neglected in a Danish context.

The paper begins by explicating why it is important to consider networks when we want to examine and work to improve gender equality in Danish academia. Afterwards, we present our review approach before moving on to present the two streams of literature. Next, we discuss how the two perspectives can complement each other and inform studies and discussions of gender inequality in Danish academia. The paper concludes by briefly outlining some focus points for future research.

\section{WHY CARE ABOUT THE ROLE OF GENDER AND NETWORKS IN DANISH ACADEMIA?}

Despite often being grouped together with the other Nordic countries as world equality 'spearheads', Denmark lags behind (Schwab et al. 2018; European Commission 2019). With respect to gender equality in academia specifically, Norway, Sweden, Finland and Iceland outperform Denmark. The share of female full professors in the former four countries range between 24 and 27 percent, whereas female professors in Denmark make up 19 percent (DMES 2017). Furthermore, weighed against European averages, the share of female master graduates at Danish universities is comparatively high, while the share of women among tenured faculty is comparatively low (European Commission 2015 cited by DMES 2017). In other words, the attrition of women in academia is greater in Denmark than in other European countries.

This problem is hardly a new discovery. The loss of female research talent has been on and off the scholarly and political agenda in Denmark for roughly 30 years. The
'Gender in Academia' research project (e.g. Bloch 1999; Henningsen 2002) and subsequent decades of knowledge production have provided invaluable insights into the gendered nature of the academic institution (e.g. Egeland 2001; Søndergaard 2006; Nielsen 2015). Knowledge of gender bias in Danish academia has led to political initiatives involving recommendations for actions considered 'best practice' with respect to raising the share of women in research (DMES 1997; 2005; 2015). Whereas today, all universities have gender equality policies, they differ markedly in their level of ambition and extent of actions taken (DMES 2017). A few universities have experimented with progressive steps to promote equality, such as financial incentives to hire more women, which have spurred much debate and, at times, outright backlash (DMES 2015; Nielsen 2014). Consequently, most universities opt for the more innocuous gender equality initiatives available, such as career training or mentoring schemes. Such strategies are often referred to as 'fix the women' actions (Ely and Meyerson 2000). The literature critiques such initiatives (e.g. Kolb et al. 2003) with reference to the complex and gendered nature of academia. While individual women may feel empowered by mentoring and training schemes, these strategies alone will not lead to substantial gender change at Danish universities (Nielsen 2017b).

Therefore, in attempts to 'fix the institution' rather than the women, limiting 'unconscious bias' in selection and recruitment processes are currently 'en vogue' (DMES 2017). However, as stressed by Nielsen (2017a; 2018), much pre-selection occurs before formalized selection and recruitment procedures even begin. Pre-selection are informal actions, such as sharing information, advertising vacancies, sponsoring, promoting and connecting colleagues, which may all affect the career opportunities of individuals (Ibid.; Benschop 2009; van den Brink and Benschop 2013). Such 
informal practices are likely to occur in the context of networks. When judgments as to who is worthy of, for example, valuable information or sponsorship occur on a discretionary basis, they are vulnerable to biases (de Vries and Binns 2018). We therefore posit that this awareness of bias beyond the recruitment process calls for an increased focus on social network structures of male and female academics, how they are formed as well as their implications for academic activities and career outcomes. Improved knowledge of gender and networks will shed new light on our understanding of persistent gender disparities in Danish academia.

\section{METHODOLOGICAL CONSIDERATIONS AND CHALLENGES}

Our review does not seek to be exhaustive of scholarly work on gender and networks. It may more adequately be considered a narrative review that is selective in the material it uses with the objective of informing a concrete empirical problem as well as future research (Lewis 2014; Cronin et al. 2008; Hammersley 2001). Below, we present the process of developing this review as well as the main methodological considerations and challenges we faced.

This paper constitutes the first step of a research project entitled Gender and Networks in Early-Career Academic Advancement. Our initial aim was exploratory, and the findings of the review were meant to inform a large-scale survey and an in-depth interview study. We conducted a literature search in Scopus and Web of Science in March 2018 using the keywords gender (sex, male, female, woman, man, women, men) and networks (networking, social capital) and organization (workplace, employee, management, higher education, work). We included publications in English from the period 1990-2018. This search resulted in a list of 1,348 references covering a wide range of theoretical and methodological approaches. Based on information such as date of publication, title, journal/publisher and abstract, we decided which sources to include. This process resulted in a list of 220 references.

Through a second, in-depth review of the remaining 220 references, we identified contributions that fulfilled the following criteria. The articles:

- concern prof./w-r networks ...

- concern high-income, high-ed ...

- have an explicit focus ...

- take a social science perspective ...

It is of course difficult to completely separate personal and professional networks since colleagues may, for instance, also be friends. Nevertheless, our choice to not include studies focusing on personal networks rests on the fact that no references in the initial literature search combined their focus on personal networks - friends, families and so on - with professional and career outcomes. Furthermore, while contemporary feminist researchers (incl. Acker 2006; Kantola and Nousiainen 2009; Ahmed 2012) might argue that intersectional approaches are required to change gender inequality, the concept of intersectionality is not widely adopted in gender equality policy or practice in Danish academia, which still largely addresses 'women' as a comprehensive, unifying category (e.g. DMES 2015; 2017) Therefore, we limit our scope to work on gender and sex.

The second selection round resulted in a list of 41 references. We each read a third of the papers and summarized the individual articles. The summaries were subsequently analyzed in order to identify similarities and differences between the contributions. In this process, we approached the summaries inductively, which resulted in two distinctions:

1. The conceptualization of gender: Is gender conceptualized and operationalized as a bina- 
ry category, or is gender conceptualized and examined as the process of gendering?

2. The focus and scope of the article: Is the article examining the effect of gender differences in networks and networking on a particular outcome, or is the article examining the construction of gender and networks in organizational activities?

The contributions were grouped into two different categories based on the distinctions above. More specifically, contributions conceptualizing and operationalizing gender as a binary category and focusing on outcomes were categorized into what we labelled the social networks literature, while contributions conceptualizing gender as the process of gendering and focusing on the construction of gender were categorized into what we labelled the gendering networks literature. Some contributions fell within both categories (see the table in the appendix for an overview of the contributions and how they are categorized).

A close scrutiny of the condensed list of papers showed that the two strings of literature only to a limited extent engaged with each other. For example, the social networks literature rarely engages with the work of gender scholars when conceptualizing gender and discussing gender dynamics of networks. Therefore, with this paper, we seek to combine key insights of the literatures in order to advance our understanding of gender and network dynamics.

Finally, along the way, additional texts were added after we had read through the reference lists of the condensed list of articles - mainly contributions from before 1990 (e.g. Miller et al. 1981; Brass 1985) and work that contributed with needed knowledge on specific points, such as the literature on masculinities (Connell 1995; Connell and Messerschmidt 2005) and gendered organizations (Acker 1990; Lorber 1994). In total, 45 titles have formed the basis of analysis of this paper (see appendix). Because of our particular literature search strategy, most of the papers of the condensed list focus on Western contexts, and publications that address the issue of gender in the labor market more broadly are not included.

In the following section of the paper, we adress the first part of our research question, namely, what characterizes the social networks literature and the gendering networks literature.

\section{THE SOCIAL NETWORKS LITERATURE}

With its focus on inequalities in career outcomes, the social networks literature looks at gender differences in the network structures of men and women as well as their networking behaviors. The social networks literature, which is dominated by quantitative studies, is generally characterized by complex and ambiguous findings (Stackman and Pinder 1999). For instance, while several studies suggest that the gains of network positions are different for men and women (e.g. Miller et al. 1981; Ibarra 1997), other studies find that gains of networking behaviors are different for men and women (e.g. Forret and Dougherty 2004). Furthermore, some studies find that men and women 'do' networking differently and that this explains differences in career gains (Gremmen et al. 2013; Stackman and Pinder 1999), while others find very little difference in the ways in which women and men practice networking (e.g. Smith 2000). Studies within this literature have further explored the moderating effects of gender on the relationship between networks and career outcomes. These studies illustrate that not only do differences in the structures of networks and networking behaviors result in unequal career outcomes for men and women; men and women also benefit differently from the same network positions and networking behaviors (e.g. Ibarra 1997; Smith-Doerr 2004; Whittington 2018). For example, in her analysis of collaborative relationships and patenting in 
the life sciences, Whittington finds differences in the returns that men and women receive from different kinds of networks. Men receive greater returns (in the form of patents) from brokerage ties and when collaborating with men, while women benefit from collaborating with women.

Although studies in the social networks literature generally present diverse findings, one phenomenon that is widely established is homophily (Ibarra 1992; 1997; Whittington 2018). Homophily is defined as the extent to which an individual is tied to other individuals who have similar characteristics, such as gender, race, age, class or any other distinguishing traits (McPherson et al. 2001). Gender homophily tends to be much more prevalent in men's than in women's networks (e.g. Metz and Tharenou 2001; Spurk et al. 2015). Broadly speaking, homophily may be the result of chance or choice (e.g. Marsden 1988; Schrum et al. 1988). Chance homophily refers to how individuals collaborate and socialize with the people available. Male homophily is often the case in organizations that have historically been dominated by men, such as universities. This way, in research environments where men constitute the majority especially at senior levels, the optimal (professional) network ties that academics can have are male. However, some studies find that even after the gender composition of the workplace has been controlled for, the homophily tendency persists (Spurk et al. 2015). This indicates that chance is not the only explanation for homophily trends in men's networks. Instead, these tendencies may also be a result of choice homophily, which refers to mechanisms at the individual level. People tend to be attracted to and feel most comfortable around others who are similar to themselves (Lipman-Blumen 1976; Byrne 1971), which generally leads to gender-specific professional networks. In sum, whether a question of choice or chance, homophily represents a constraining struc- ture for women, while it constitutes a career advantage for men (Spurk et al. 2015; Metz and Tharenou 2001). The tendency of homophily, identified by the social networks literature, is thus an important aspect of gender inequalities in career outcomes within male-dominated fields, such as academia.

Common for the studies within the social networks literature is their focus on mapping differences in network structures, practices and returns (such as homophily) and exploring how these differences affect career outcomes. The question of how these patterns in networks arise receive less attention. In the following section, we present and discuss the gendering networks literature, which seeks to unfold networking as a multi-faceted practice with the aim of obtaining a deeper understanding of gendered processes of in- and exclusion.

\section{THE GENDERING NETWORKS LITERATURE}

Whereas the social networks literature focuses on mapping network structures and pointing to potential outcomes, the gendering networks literature studies the role of actors, that is, how they behave, and how they experience network interactions (van den Brink and Benschop 2013, 2). The gendering networks literature sees networking as a social practice entangled in unreflective everyday interactions in workrelated contexts and therefore builds on qualitative research approaches such as observational studies, which makes it possible to capture unreflective gendered inclusionexclusion mechanisms in everyday interactions (Benschop 2009). In cases where observation is not possible, interviews represent 'the next-best thing', allowing researchers to capture at least accounts of practices, although not practices themselves (van den Brink and Benschop 2013, 9).

The gendering networks stream is further characterized by approaching gender 
as a social practice (West and Zimmermann 1987; Acker 1990; Lorber 1994), which brings to the fore how much human interaction revolves around distinguishing between man and woman, masculinity and femininity. Such distinctions are created and negotiated in everyday practices between people and are contingent on discursive, organizational and social contexts. In other words, in this literature, gender is understood as a fundamental organizing principle from which follows that gender practices are unconscious and largely invisible even to their practitioners (Fletcher 1999; van den Brink and Benschop 2013, 6).

In this stream, most studies emphasize that masculine and feminine networking behaviors are not tied to male and female bodies (e.g. Benschop 2009). Indeed, in the professional realm, women are often required to engage in behaviors that in Western cultures are perceived as 'masculine' in order to avoid the stereotypes of women as 'other', which masculine hegemonic organizations produce (Knights and Kerfoot $2004,447)$. Berger et al. $(2015,566)$ argue that women have to downplay their gender because of the risk that their feminine traits will detract from their assumed professionalism. At the same time, engaging in counter-stereotypical behaviors may also imply a risk of social sanctions for women as well as men. For example, van den Brink and Benschop (2013) find that men use networks for self-promotion and boasting, while such 'unfeminine' behaviors are not equally available to women.

Occurring in the immediacy of interactions, people rarely reflect on their behaviors as 'gendered' or having gendered consequences (Martin 2006). Still, the gendering networks literature points to how exclusion of women can occur when men act in concert to do masculinities (e.g. Connell 1995; Connell and Messerschmidt 2005) a practice that is sometimes labelled mobilizing masculinities (Martin 2001). Van den Brink and Benschop (2013) theorize mobilizing masculinities as 'male bonding', that is, a collective practice of men connecting to each other. Male bonding may be assessed as a spectrum of actions ranging from seemingly banal interactions without explicit gendering, over friendly teasing and increasingly rough mockery to bullying and, finally, at the other extreme, outright sexism and misogyny (ibid.). At the harmless end, male bonding may simply imply men talking about shared interests that are widely presumed not to be shared by women to the same extent. In the middle of the spectrum, behaviors include certain kinds of mockery, banter and verbal dueling among men (Kotthoff 2006). Gender is not necessarily explicitly addressed. However, such interactions may still be implicitly gendered when carrying masculine connotations, in which cases women are less likely to take part. Berger et al. (2015) argue this point by stating that engaging in aggressive humor is risky for women as this practice may constitute a violation of gender norms. At the more severe end of the spectrum, aggressive forms of humor may be employed with explicit reference to women or femininity. By drawing attention to women's gender, focus is placed on features of the object of a remark that lie outside of the professional world and that, in this way, detract from the image of professional competence (Berger et al. 2015, 566). When remarks are made as jokes, women are expected to receive such 'tough love' passively, even laugh, because objecting makes you a 'nag' (Kotthoff 2006).

In the work by Benschop and her associates (Benschop 2009; van den Brink and Benschop 2013; Berger et al. 2015), female research participants are often bothered by 'man talk', but in order to be accepted in their academic environments, they refrain from resisting when they are problematically, stereotypically gendered. Finally, women's attempts to be included in male networks also tend to be jeopardized by perceptions of possible sexual undertones, 
which leaves in particular women vulnerable to criticism, gossip and 'shaming' (ibid.).

In sum, beyond analyzing how gender is performed in work- and network-related contexts, from a feminist social constructivist point of departure, the gendering networks literature aims to unveil how gender hierarchies are constructed, perpetuated or countered through gendered practices. Gendered practices in academic networking may individually seem innocuous. However, cumulatively, these complex and interdependent processes may imply that women are left out of - or deliberately stay away from - men's formal and informal gatherings, networks and, ultimately, professional opportunities (van den Brink and Benschop 2013, 21).

\section{COMbINING THE TWO PERSPECTIVES}

As the presentation above illustrates, the two streams of literature both address the issue of networks and gender but focus on different aspects and questions. The social networks literature examines network structures and their implication for career outcomes for men and women. The gendering networks literature, on the other hand, focuses on how gender hierarchies are constructed through gendered practices. With the exception of van den Brink and Benschop (2013), such hierarchies are only implicitly related to potential implications for career prospects. In the following, we seek to answer the second part of our research question: How can the two literatures inform each other and advance our understanding of gender dynamics in academic networks?

As the section above shows, the social networks literature uncovers gender differences, network positions and network structures but provides limited insight into how these differences are formed. In order to understand why gender differences in network structures and network positions arise, it is necessary to ask how gender is actualized in interactions at the university. This is where the gendering networks literature can contribute both with theoretical perspectives and methodological approaches. However, limiting our focus to examining how gender is constructed and what gender comes to mean in academic life is not enough if we want to explain outcomes and effects of these processes. This can be illustrated with the example of homophily in networks. As previously mentioned, one of the most consistent findings within the social networks literature is homophily tendencies. These studies indicate that homophily trends are contributing to gender inequality in career outcomes and cannot only be explained by the gender composition of the organization. This finding begs the following questions: What does choice homophily mean? How does it play out in practice, and how is it experienced by individuals in the organization? In the social networks literature, it is argued that individuals are generally attracted to other individuals similar to themselves, leading to gender-specific professional networks. This argument seems to imply that homophily is due to more or less automatic or unreflected responses from people. However, the gendering networks literature suggests that this is not the only reason. These studies show how inclusion and exclusion of individuals are instead the result of liminal patterns of social practice in which understandings of masculinity and femininity are constructed and reproduced. On the other hand, the social networks literature informs the gendering networks literature by showing how gendered mechanisms at play in the social practices of individuals, which often lead to the exclusion of women, are also manifest in more general patterns in professional networks. Moreover, the social networks literature explicitly links differences in network structures (such as homophily in men's networks) to career outcomes. Social networks studies are capable 
of demonstrating such patterns through their quantitative mappings of networks. Combining the two approaches hence gives us a more comprehensive understanding of the relationship between gender and networks in organizations. In other words, the social networks literature maps network structures, and the gendering networks literature takes us on a journey through these structures.

\section{IMPLICATIONS FOR INEQUALITY IN DANISH ACADEMIA}

The synergies of combining the two literatures extend beyond the theoretical level since, together, they hold the promise of informing gender equality work more adequately than each stream individually. Gender equality work here refers to the types of initiatives that are employed at Danish universities to try to retain more women in research careers. While female researchers' lack of access to influential networks, and the detrimental effects this may have for women in research, is generally recognized (DMES 2005; 2015), adequate solutions are lacking. Too often, women are simply encouraged 'to network' better or more, a suggestion that is naively oblivious to the gender dynamics at play in networks, as the literature has robustly established. Alternatively, organizations may create women-only networks, but whether this strategy is able to significantly boost women's career opportunities is contested in the literature (see e.g. Pini et al. 2004). Mentorship is also regularly proposed as a remedy to strengthen women's networks, presupposing that mentoring relationships go beyond advising and involve sponsoring practices (de Vries and Binns 2018), which may not always be the case. All these types of initiatives tend to be directed at the individual level and aim at changing the behavior and capabilities of the individual (woman). The preference for such initiatives may be attributed to academia's strong belief in mer- itocracy (Bagilhole and Goode 2001; Krefting 2003). In the private sector, exploiting and benefitting from networks in career advancement constitutes a legitimate and openly encouraged practice. In academia, on the other hand, hegemonic discourses still widely perpetuate the myth that universities are gender-neutral and equal organizations in which career success comes down to 'academic excellence' (Lund 2015; Nielsen 2016).

However, both the social networks literature and the gendering networks literature show how networks and networking are relational phenomena, which suggests that gender equality work should increasingly look at network structures as well as everyday networking practices from an organizational perspective instead of focusing on promoting specific competences and behaviors among individual researchers. This entails mapping networks and uncovering general gendered outcomes of network structures and behaviors within the organization (the social networks approach). Moreover, also in the area of networks, gender is not just a pre-given indicator, but a product of gendered contexts. To address exclusionary contexts and interactions and bring into light how networks foster and limit the career opportunities of particular people, including women, the gendering networks approach is required.

\section{FutURE RESEARCH}

We conclude our review by outlining three aspects that we believe future research should focus on in order to advance this field of study. First, we encourage scholars to focus on linking network structures at the organizational level with the lived experiences of gender and networks of individuals. This calls for mixed-methods projects focusing on 1) the mapping of networks, combined with 2) exploring the meanings of gender and the lived experiences of gender and networks. Second, the studies 
within the social networks literature are not unambiguous in their findings, which points to the complexity and context dependency of the interplay between gender and networks. Therefore, future studies should explore these ambiguities and examine in depth the possibilities and constraints that individual researchers experience in relation to networks and networking in academia, for example, by adopting more explorative and qualitative approaches. Questions that could be asked are as follows: Which kinds of strategies do researchers at different career stages pursue and why? How are such strategies received? How do these strategies vary from context to context? This leads us to the third and final aspect that we argue would be beneficial to incorporate in future studies: the academic context. As much research on gender and networks until now has studied businesses, future research should ask the following question: How do the rules and roles of academia specifically shape the interplay between gender and networks? And lastly, what are the differences across academic institutions, disciplines and environments?

\section{ACKNOWLEDGMENTS}

The authors would like to extend a warm thank you to our colleagues at the Danish Centre for Studies in Research and Research Policy, Lise Degn, Malene V. Christensen and Asger Dalsgaard, for their rich feedback, as well as to our 'teammates' in the Gender and Networks in Early-Career Academic Advancement project, Thomas Ryan and Mathias W. Nielsen, for their invaluable comments to this paper.

\section{REFERENCES}

- Acker, J. 1990. Hierarchies, Jobs, Bodies: A Theory of Gendered Organizations. Gender \& Society. 4(2), 139-158. DOI:

https://doi.org/10.1177\%2F089124390004002 002

- Acker, J. 2006. Inequality Regimes: Gender, Class, and Race in Organizations. Gender er Society. 20(4), 441-464. DOI: https://doi.org/ 10.1177\%2F0891243206289499

- Ahmed, S. 2012. On Being Included: Racism and Diversity in Institutional Life. Durham, NC: Duke University Press.

- Bagilhole, B. and Goode, J. 2001. The Contradiction of the Myth of Individual Merit, and the Reality of a Patriarchal Support System in Academic Careers: A Feminist Investigation. European Journal of Women's Studies. 8(2), 161-180. DOI: https://doi.org/10.1177/135050680100800203 - Benschop, Y. 2009. The Micro politics of Gendering in Networking. Gender, Work \& Organization. 16(2), 217-237. DOI:

https://doi.org/10.1111/j.1468-

0432.2009.00438.x

- Berger, L., Benschop, Y. and van den Brink, M. 2015. Practising Gender When Networking: The Case of University-Industry Innovation Projects. Gender, Work and Organization. 22(6), 556-578. DOI: https://doi.org/10.1111/gwao.12104|

- Bloch, C. 1999. Køn i akademia - ud fra Bourdieus blik. Køn $i$ den akademiske organisation: working paper, no. 8. Institut for Statskundskab, Københavns Universitet.

- Brass, D. J. 1985. Men's and Women's Networks: A Study of Interaction Patterns and Influence in an Organization. The Academy of Management Journal. 28(2), 327-343. DOI:

http://dx.doi.org/10.2307/256204

- Byrne, D. 1971. The Attraction Paradigm. New York: Academic Press.

- Caprile, M. et al. 2012. Meta-analysis of gender and science research, Synthesis report. Luxembourg, Publications Office of the European Union.

- Connell, R. 1995. Masculinities. Cambridge, UK: Polity Press.

. Connell, R. and Messerschmidt, J. 2005. Hegemonic Masculinity: Rethinking the Concept. Gender \& Society. 19(6), 829-859. DOI: https://doi.org/10.1177/0891243205278639 - Cronin, P., Ryan, F. and Coughlan, M. 2008. Undertaking a Literature Review: A Step-by-Step Approach. British Journal of Nursing. 17(1), 3843. DOI: 10.12968/bjon.2008.17.1.28059

- Danish Ministry of Education and Science. 2005. Alle talenter i spil - Fleve kvinder i forskning. 
[Online]. Available from: http://ufm.dk/publikationer $/ 2005$ /alle-talenter-i-spil-flere-kvinder-iforskning.

- Danish Ministry of Education and Science. 2015. Anbefalinger fra Taskforcen for Flere Kvinder $i$ Forskning. [Online]. Available from:

http://static.sdu.dk/mediafiles//A/3/6/\%7BA3 6D49A3-C2BD-4EA4-BF08-

687EA91BD8E3\%7Danbefalinger-fra-taskforcenfor-flere-kvinder-i-forskning.pdf.

- Danish Ministry of Education and Science. 2017. Mand og kvinder på de danske universiteter - Danmarks talentbarometer 2017. [Online]. Available from:

https://ufm.dk/publikationer/2017/filer/maend-og-kvinder-pa-de-danske-universiteter-danmarks-talentbarometer-2017.pdf.

- de Vries, J. and Binns, J. 2018. Sponsorship: Creating Opportunities for Women in Higher Education. Canberra, Australia: Universities Australia Executive Women (UAEW). [Online]. Available from:

https://staticl.squarespace.com/static/506ad3da e4b00f5f2f4c9f0a/t/5bf36b618985834e028f5eb c/1542679426732/Sponsorship+Guide_Final.pdf. - Egeland, C. 2001. 'Men det har ikke noget med kønnet at gøre': køn, kønsbarrierer og Akademiakonstruktioner af et ugyldigt problem. $\mathrm{PhD}$ dissertation. Center for Kvinde- og Kønsstudier. Odense: University of Southern Denmark.

- Ely, R. J. and Meyerson, D. E. 2000. Theories of Gender in Organizations: A New Approach to Organizational Analysis and Change. Research in Organizational Behaviour. 22, 103-151. DOI: https://doi.org/10.1016/S0191-

3085(00)22004-2

- European Commission. 2015. She Figures 2015. Directorate-General for Research and Innovation and Directorate B - Open Innovation and Open Science, Brussels.

- European Commission. 2019. She Figures 2018. Directorate-General for Research and Innovation and Directorate B - Open Innovation and Open Science, Brussels.

- Fletcher, J. 1999. Disappearing Acts: Gender, Power, and Relational Practice at Work. Cambridge, MA: MIT Press.

- Forret, M. L. and Dougherty, T. W. 2004. Networking Behaviors and Career Outcomes: Differences for Men and Women? Journal of Organizational Behavior. 25(3), 419-437. DOI: http://dx.doi.org/10.1002/job.253 - Fox, M. F., Whittington, K. B., \& Linkova, M. 2017. Gender, (In)Equity, and the Scientific Workforce. Fourth edition. In: Felt, U., Fouche,
R., Miller, C., and Smith-Doerr, L. eds. Handbook of Science and Technology Studies. Cambridge, MA: MIT Press.

- Gremmen, C., Akkerman, A. and Benschop, Y. 2013. Does Where You Stand Depend on How You Behave? Networking Behavior as an Alternative Explanation for Gender Differences in Network Structure. Journal of Management \& Organization. 19(3), 297-313. DOI:

https://doi.org/10.1017/jmo.2013.27

. Hammersley, M. 2001. On 'Systematic' Reviews of Research Literatures: A 'Narrative' Response to Evans \& Benefield. British Educational Research Journal. 27(5), 543-554. DOI:

https://doi.org/10.1080/014119201200957261

- Henningsen, I. 2002. 30 års march på stedet? Konsprofilen blandt de videnskabeligt ansatte på Københavns Universitet 1970-2001. Køn i den akademiske organisation: working paper, no. 13. Institut for Statskundskab, Københavns Universitet. - Ibarra, H. 1992. Homophily and Differential Returns - Sex-Differences in Network Structure and Access in an Advertising firm. Administrative Science Quarterly. 37(3), 422-447. DOI:

$10.2307 / 2393451$

- Ibarra, H. 1997. Paving an Alternative Route: Gender Differences in Managerial Networks. Social Psychology Quarterly. 60(1), 91-102. DOI: $10.2307 / 2787014$

- Kantola, J. and Nousiainen, K. 2009. Institutionalizing Intersectionality in Europe. International Feminist Journal of Politics. 11(4), 459-477. DOI: https://doi.org/10.1080/14616740903237426

- Knights, D. and Kerfoot, D. 2004. Between Representations and Subjectivity: Gender Binaries and the Politics of Organizational Transformation.

Gender, Work \& Organization. 11(4), 430-454.

DOI: https://doi.org/10.1111/j.1468-

0432.2004.00241.x

- Kolb, D., Fletcher, J. K., Meyerson, D., Sands, D. M. and Ely, R. J. 2003. Making change: A framework for promoting gender equity in organizations. In: Ely, R., Foldu, E., Scully, M. and the Center for Gender in Organizations. eds. Reader in gender, work, and organization. Malden, MA: Blackwell, 3-9.

- Kotthoff, H. 2006. Gender and Humor: The State of the Art. Journal of Pragmatics. 38(1), 425. DOI:

http://dx.doi.org/10.1016/j.pragma.2005.06.00 3

- Krefting, L. 2003. Intertwined Discourses of Merit and Gender: Evidence from Academic Employment in the USA. Gender, Work or Organization. 10(2), 260-278. DOI: 
http://dx.doi.org/10.1111/1468-0432.t01-100014

- Lewis, P. 2014. Postfeminism, Femininities and Organization Studies: Exploring a New Agenda. Organization Studies. 35(12), 1845-1866. DOI: https://doi.org/10.1177/0170840614539315 . Lipman-Blumen, J. 1976. Toward a Homosocial Theory of Sex Roles: An Explanation of the Sex Segregation of Social Institutions. Signs. 1(3), 1531. DOI: https://doi.org/10.1086/493272 - Lorber, J. 1994. Paradoxes of Gender. US: Yale University Press.

. Lund, R. 2015. Doing the Ideal Academic - Gender, Excellence and Changing Academia. Doctoral Dissertation. Espoo, Finland: Aalto University. - Martin, P. 2001. 'Mobilizing Masculinities': Women's Experiences of Men at Work. Organization. 8(4), 587-618. DOI: https://doi.org/10.1177/135050840184003

- Martin, P. 2006. Practising Gender at Work: Further Thoughts on Reflexivity. Gender, Work \& Organization. 13(3), 254-276. DOI:

https://doi.org/10.1111/j.1468-

0432.2006.00307.x

- Marsden, P. 1988. Homogeneity in Confiding Relations. Social Networks. 10(1), 57-76. DOI: http://dx.doi.org/10.1016/0378-

8733(88)90010-X

- McPherson, M., Smith-Lovin, L. and Cook, J. M. 2001. 'Birds of a Feather': Homophily in Social Networks'. Annual Review of Sociology. 27, 415-444. DOI: https://doi.org/10.1146/annurev.soc.27.1.415

- Metz, I. and Tharenou, P. 2001. Women's Career Advancement: The Relative Contribution of Human and Social Capital. Group o Organization Management. 26(3). 312-342. DOI: https://doi.org/10.1177/1059601101263005

- Miller, J., Lincoln, J. R. and Olson, J. 1981. Rationality and Equity in Professional Networks: Gender and Race as Factors in the Stratification of Interorganizational Systems. American Journal of Sociology. 87(2), 308-335. DOI:

https://doi.org/10.1086/227460

- Nielsen, M. W. 2014. Justifications of Gender Equality in Academia: Comparing Gender Equality Policies of Six Scandinavian Universities. NORA Nordic Journal of Feminist and Gender Research. 22(3), 187-203. DOI:

https://doi.org/10.1080/08038740.2014.9054 90

- Nielsen, M. W. 2015. New and Persistent Gender Equality Challenges in Academia, Aarhus: Politica's Ph.D. Series, Department of Political Science, Aarhus University.
- Nielsen, M. W. 2016. Limits to Meritocracy? Gender in Academic Recruitment and Promotion Processes. Science and Public Policy. 43(3), 386399. DOI:

https://doi.org/10.1093/scipol/scv052

- Nielsen, M. W. 2017a. Reasons for Leaving the Academy: a Case Study on the 'Opt Out' Phenomenon among Younger Female Researchers. Gender, Work \& Organization. 24(2), 134-155. DOI: https://doi.org/10.1111/gwao.12151/ - Nielsen, M. W. 2017b. Scandinavian Approaches to Gender Equality in Academia: A Comparative Study. Scandinavian Journal of Educational Research. 61(3), 295-318. DOI:

https://doi.org/10.1080/00313831.2016.1147 066

- Nielsen, M. W. 2018, August 22. Keynote at 10th Conference for Gender Equality in Higher Education, Trinity College, Dublin, Ireland.

. Pini, B., Brown, K. and Ryan, C. 2004.

Women Only Networks as a Strategy for Change? A Case Study from Local Government. Women in Management Review. 19(6), 286-292. DOI:

10.1108/09649420410555051

- Shrum, W., Cheek, N.H., Hunter, S.M. (1988). Friendship in school: Gender and racial homophily. Sociology of Education. 61, 227-239. DOI: http://dx.doi.org/10.2307/2112441

- Schwab, K., Samans, R., Zahadi, S., Leopold, T. A., Ratcheva, V., Hausman, R. and Tyson, L. 2018. Global Gender Gap Report 2018. World Economic Forum.

- Smith-Doerr, L. 2004. Flexibility and Fairness: Effects of the Network Form of Organization on Gender Equity in Life Science Careers. Sociological Perspectives. 47(1), 25-54. DOI:

https://doi.org/10.1525/sop.2004.47.1.25

- Smith-Doerr, L. and Powell, W. 1994. Networks and Economic Life. In: Smelser, N. J. and Swedberg, R. The Handbook of Economic Sociology. Princeton, N. J.: Princeton University Press, 379402.

- Smith, S. 2000. Mobilizing Social Resources: Race, Ethnic and Gender Differences in Social Capital and Persistent Wage Inequalities. The Sociological Quarterly. 41 (4), 509-537. DOI: https://doi.org/10.1111/j.1533-

8525.2000.tb0007l.xl

- Spurk, D., Meinecke, A. L., Kau eld, S. and Volmer, J. 2015. Gender, Professional Networks, and Subjective Career Success within Early Academic Science Careers. Journal of Personnel Psychology. 14(3), 121-130. DOI:

http://dx.doi.org/10.1027/1866-

5888/a000131 
. Stackman, R. and Pinder, C. 1999. Context and Sex Effects on Personal Work Networks. Journal of Social and Personal Relationships. 16(1), 39-64. DOI:

https://doi.org/10.1177/0265407599161003 - Søndergaard, D. M. 2006. Tegnet på kroppen: køn: koder og konstruktioner blandt unge voksne $i$ Akademia. København: Museum Tusculanum. - van den Brink, M. and Benschop, Y. 2013. Gender in Academic Networking. Journal of Management Studies. 51(3), 460-492. DOI:

https://doi.org/10.1111/joms.12060|
- West, C. and Zimmerman, D. 1987. Doing Gender. Gender \& Society. 1(2), 125-151. DOI: https://doi.org/10.1177/08912432870010020 02

- Whittington, K. B. 2018. A Tie Is a Tie? Gender and Network Positioning in Life Science Inventor Collaboration. Research Policy. 47(2), 511-526. DOI: https://doi.org/10.1016/j.respol.2017.12.006 